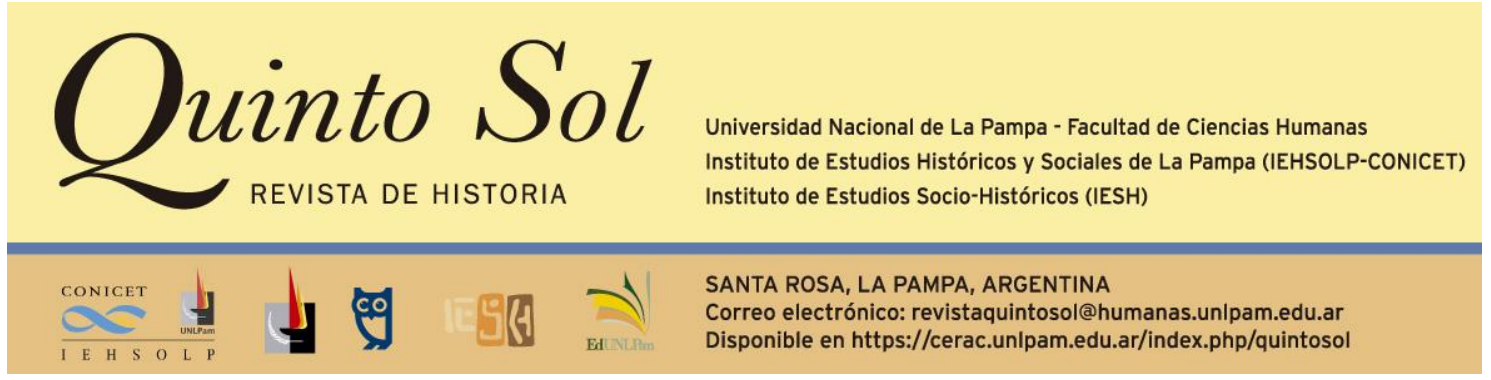

Quinto Sol, vol. 25, n², mayo-agosto, ISSN 1851-2879, pp. 1-3

http://dx.doi.org/10.19137/qs.v25i2.5289

Esta obra se publica bajo licencia Creative Commons 4.0 Internacional. (Atribución-No ComercialCompartir Igual)

\title{
María Cristina Ockier. Fortineras, mujeres en las fronteras. Ejércitos, guerras y género en el siglo XIX. Imago Mundi, 2020, 326 páginas.
}

\section{Estrella B. laconis Serraino}

Universidad Nacional de La Pampa. Facultad de Ciencias Humanas

Argentina

Correo electrónico: estrellaiaconis@gmail.com

El presente libro recupera los resultados obtenidos en la tesis de maestría en género de Ockier. La autora se ha dedicado a la historia del alto valle del Río Negro, particularmente al período correspondiente a la "Conquista del desierto", y en este trabajo continuó en esa línea de estudio en clave de género. En las últimas décadas los estudios en perspectiva de género se han incrementado y en gran medida se debe al esfuerzo de los movimientos feministas. Empero, los trabajos previos que refieren a las fortineras, las mujeres de las que se ocupa Ockier, se han limitado a un carácter sobre todo descriptivo, que sin duda han contribuido en el rastreo y conocimiento de las mismas al momento de elaborar el estudio más reflexivo y analítico que aquí se reseña. Ockier no solo va a dar cuenta de las actividades que realizaban dichas mujeres en los campamentos, sino que además devela el entramado de jerarquías y poderes en las relaciones sociales que se construyeron en base al patriarcado. $Y$ en relación a ello observó cómo las mujeres resultaron desplazadas de las tareas socialmente consideradas de mayor relevancia, entre ellas la actividad militar.

El libro se estructura en tres partes. En la primera, que consta de dos capítulos, la autora se pregunta: “¿Dónde radica la particularidad del quehacer militar? En los 
fortísimos significados y representaciones de género que lo atraviesan" (p. 5). De este modo, pretende desmentir la idea biologicista de que las mujeres son incapaces de ejercer violencia. Concepto que ha conllevado a representar a las mujeres guerreras Juana de Arco, las amazonas, Boadicea, entre otras- como figuras excepcionales, personajes románticos, no naturales. La autora realizó un recorrido histórico e historiográfico sobre diversos estudios que han analizado el papel de las mujeres en la guerra en diferentes contextos. Primeramente, lo hizo a una escala internacional e incluyó no solo relatos de mujeres occidentales, sino también orientales, para luego acercarse a los estudios latinoamericanos que han recuperado las voces de las mujeres que intervinieron en diferentes batallas, entre ellas: las amazonas, las paceñas, las cochabambinas que participaron en las Guerras de Independencia, las matriarcas, andarilhas y vivandeiras del Brasil que estuvieron en la Guerra del Paraguay, y las adelitas de la Revolución Mexicana. Asimismo, menciona a mujeres individuales, como Machaca Güemes, Juana Moro, Javiera Carrera y muchas más... Todas fueron enmarcadas bajo dos estereotipos o representaciones: de víctima o de bravura. El androcentrismo ha conllevado a crear esas imágenes dado que no es "natural" que una mujer tome las armas o ejerza la violencia.

En la segunda parte, compuesta de tres capítulos, se adentró al caso de las fortineras, mujeres que fueron partícipes de la "Campaña al desierto". Si bien Ockier refiere a otras zonas de la frontera, expresa que su foco de interés está centrado en la frontera sur de Buenos Aires, desde donde partieron los regimientos que avanzaron hacia el río Negro. Para comenzar, desarrolla el contexto de la campaña, los motivos de esa empresa militar y su duración, de ese modo posibilita a las y los lectores adentrarse en el proceso que narra. La investigadora plantea que la campaña se desenvolvió en tres etapas que abarcan desde el período hispánico hasta fines del siglo XIX. El recorrido de cada una de ellas da cuenta de cómo fue cambiando el cariz de la empresa militar según los intereses políticos y económicos, y cómo se iba tornando más o menos ofensiva según las circunstancias.

Después de describir cómo era el panorama en la frontera, la autora se pregunta por qué esas mujeres se enrolaban en tal actividad: ¿será por un espíritu nacional, como mencionan los escritos de sus contemporáneos? Nada de eso. Ella menciona como causales principales las políticas represivas que existían tanto para hombres como mujeres que no cumplían su rol como ciudadanos/as. Al igual que los varones, podían ser castigadas por "vagas" o por ser mujeres de "vida pública", y por ende eran enviadas a la frontera. Además, si eran casadas, ¿qué podía hacer una mujer de la campaña que quedaba sola a su suerte cuando su marido era enviado a la frontera? Dado los escasos recursos de los que disponían, formar parte del regimiento era su mejor opción.

En la última parte de este trabajo, la autora suma al género las categorías de clase y etnia. ¿Quiénes conformaban las filas? Mujeres mestizas, de la campaña, rurales, del interior e indígenas que eran capturadas durante la avanzada militar. Estas últimas, tomadas a las fuerza, fueron denigradas y animalizadas por sus atributos, no solo se hizo uso de sus cuerpos de manera sexuada sino también discursivamente para reproducir una vez más jerarquías sociales. De este modo, el androcentrismo se percibe en los escritos de sus contemporáneos y en las políticas implementadas por las instituciones. Las fortineras eran el eslabón más vulnerable en el entramado de intereses económicos y políticos. Para demostrar este punto, la investigadora examinó 
los cambios en las políticas de raciones, porque a la hora de decidir la sobrevivencia de las tropas, los niños y las mujeres eran desestimados y se reducían los suministros destinados a esos sectores. Así, se observa lo capcioso de la situación, ya que aquellas que fueron usadas como instrumentos para reducir la deserción eran a su vez marginadas según los pormenores que acontecían en las instituciones de poder.

Para concretar este trabajo, Ockier recurrió a diversas fuentes, analizó fotografías, listas de revistas, literatura contemporánea y memorias de guerra. La riqueza de su trabajo radica en el estudio que hizo de la situación de dichas mujeres en base al género, la etnia, la clase y el honor, y a su vez la vinculación con la memoria. Tales mujeres no tuvieron voz propia, sus registros provienen de varones contemporáneos. No fueron dueñas de sus cuerpos ni de sus nombres, se las recuerda por apodos como la Pasto Verde, Mamá Carmen, la Mazamorra, la Martineta; y un apodo no es algo azaroso, da cuenta de una filiación determinada que le fue impuesta. Además, esta práctica puede ser pensada como una cuestión de códigos que mantenía una unión entre los hombres más allá de sus rangos.

A modo de conclusión, Fortineras, mujeres en las fronteras. Ejércitos, guerras y género en el siglo XIX permite visibilizar la sexualización existente al interior de la estructura militar. Dado que el monopolio del uso de armas y la violencia era del hombre, la mujer fue relegada a cumplir servicios y asistencia, actividades que no las hicieran alejar demasiado de su rol de género. En aquellos casos donde tomaron las armas, se las adornó de una imagen romántica y excepcional. Es necesario romper con ese ideario y continuar con una línea de interseccionalidad, como realiza la autora. Esto última implica comprender que algunos agentes -mujeres indígenas, mestizas, de la campaña- sufrieron opresiones por su pertenencia a múltiples categorías sociales. Después de todo, de ello se trata en parte la perspectiva de género, de ser conscientes que la clase, la etnia o la orientación sexual frecuentemente actúan de manera relacionada. Este libro aporta una nueva mirada para pensar y recordar a las mujeres militares más allá de los estereotipos de abnegada, víctima o brava. 